\title{
New Black sea monothalamous foraminifera from the genus Nemogullmia Nyholm, 1953 (Allogromiida: Shepheardellinae)
}

\author{
N.G. Sergeeva*, O.V. Anikeeva \\ A.O. Kovalevsky Institute of Biology of the Southern Seas, Russian Academy of Sciences, Nakhimov \\ Prospect., 2, Sevastopol 299011, Russia. E-mail: oksana.anikeeva@gmail.com \\ * Corresponding author.E-mail: nserg05@mail.ru
}

ABSTRACT: We present the results of investigations on Black Sea soft-walled monothalamous foraminiferans (monothalamids) in the SW part of the Sea in the Bosphorus Strait's outlet area (April 2010), the NW and NE parts of the Crimean shelf(August 2013), and the NE part on the Caucasus shelf (July 2019). Three new monothalamid species in the subfamily Shepheardellinae in the Black Sea are described. Nemogullmia pontica sp.n. was found in the outer part of the Bosphorus Strait (252.4 m depth), as well as the Kerch Strait (90 m) and Karkynitsky gulf near cape Tarkhankut $(30 \mathrm{~m})$ in the NE and NW parts of the Black Sea, respectively. Nemogullmia bosphorica sp.n. originated from the Bosphorus Strait outlet area (82-135 m depth) and Nemogullmia longissima sp.n. from the region of the Kerch Strait (79-90 m depth). Several unidentified individuals of Nemogullmia were found near Cape Small Utrish region (Caucasus) at depths of 82 and $101 \mathrm{~m}$.

How to cite this article: Sergeeva N.G., Anikeeva O.V. 2020. New Black sea monothalamous foraminifera from the genus Nemogullmia Nyholm, 1953 (Allogromiida: Shepheardellinae) // Invert. Zool. Vol.17. No.2. P.176-188. doi: 10.15298/invertzool.17.2.07

KEY WORDS: Soft-shelled foraminifera; Nemogullmia pontica sp.n., Nemogullmia bosphorica sp.n., Nemogullmia longissima sp.n., the Black Sea.

\section{Моноталамусные фораминиферы рода Nemogullmia Nyholm, 1953 (Allogromiida: Shepheardellinae) новые для Черного моря}

\section{Н.Г. Сергеева*, О.В. Аникеева}

Институт биологии южных морей им. А.О. Ковалевского РАН, проспект Нахимова, 2, Севастополь 299011, Россия.E-mail: oksana.anikeeva@gmail.com

* Автор для переписки. E-mail:nserg05@mail.ru

РЕЗЮМЕ: Представлены результаты изучения черноморских моноталамусных мягкораковинных фораминифер юго-западной части моря в районе выхода пролива Босфор (апрель 2010 г.), в северо-западной и северо-восточной частях шельфа Крыма (август 2013 г.) и северо-восточной части шельфа Кавказа (июль 2019 г.). Описаны три вида рода Nemogullmia подсемейства Shepheardellinae в Черном море. Nemogullmia pontica sp.n. найдена во внешней части Босфорского пролива (глубина 252,4 м), а также в Керченском проливе (90 м) и Каркинитском заливе вблизи мыса Тарханкут (30 м) в северо-восточной и северо-западной частях Черного моря, соот- 
ветственно. Nemogullmia bosphorica sp.n. встречена в районе выхода из пролива Босфор (глубина 82-135 м), а Nemogullmia longissima sp.n. — в районе Керченского пролива (глубина 79-90 м). Также несколько неидентифицированных особей рода Nemogullmia были обнаружены на глубинах 82 и 101 м вблизи мыса Малый Утриш (Кавказ).

Как цитировать эту статью: Sergeeva N.G., Anikeeva O.V. 2020. New Black sea monothalamous foraminifera from the genus Nemogullmia Nyholm, 1953 (Allogromiida: Shepheardellinae)//Invert.Zool. Vol.17.No.2.P.176-188. doi: 10.15298/invertzool.17.2.07

КЛЮЧЕВЫЕ СЛОВА: Мягкораковинные фораминиферы, Nemogullmia pontica sp.n., Nemogullmia bosphorica sp.n., Nemogullmia longissima sp.n., Черное море.

\section{Introduction}

Three size groups of benthic organisms (macro-, meio- and microbenthos) are generally recognized, each of them playing a distinct role in the functioning of soft-bottom ecosystems. According to Mare (1942), the macrobenthos includes organisms retained on a $1 \mathrm{~mm}$ mesh, the meiobenthos are microscopic organisms in the size range $0.1-1.0 \mathrm{~mm}$, and microbenthos includes organisms less than $0.1 \mathrm{~mm}$ in size. The application of these size categories has played an important role in marine benthic investigations. However, benthic protists (gromiids, foraminifera, ciliates) are often ignored, and until near the end of the last century, one group, the soft-walled monothalamous foraminifers (monothalamids), were not mentioned at all in studies of marine benthic communities in the Black Sea. The main reason for this omission is the lack of sufficient information about this group of benthic protists, in particular regarding their morphology, which requires methods not normally employed in foraminiferal studies. The first mention of soft-walled monothalamids in the Black Sea appeared at the turn of the 20th and 21st centuries (Sergeeva, Kolesnikova, 1996; Golemansky, 1999; Sergeeva, Anikeeva, 2006). However, it is now recognized that they are an important component of benthic communities in this area. They are numerous and widely distributed from the coastal zone (normoxia conditions) to $300 \mathrm{~m}$ depth, where hypoxia and anoxia are associated with hydrogen sulfide (Sergeeva, Anikeeva, 2006, 2008, 2014, 2018;
Gooday et al., 2011; Sergeeva et al., 2012, 2013, 2015, 2017; Anikeeva et al., 2013; Sergeeva, Mazlumyan, 2013, 2015; Sergeeva, 2016).

Foraminifera in general play an important role in the transfer of bacterial and algal products to higher trophic levels. It known from our own observations (Sergeeva et al., 2017; Sergeeva, Anikeeva, 2018) and published studies (e.g., Lipps, Valentine, 1970; Murray, 2006; Suhr et al., 2008), that these protists are omnivorous, feeding on small bacteria, algae, pollen of terrestrial vegetation, fragments of marine mycelial fungi, as well as on protozoans and multicellular invertebrates. In turn, they serve as an important source of food for many benthic invertebrates in various habitats. Foraminifera can be grouped informally into hard-shelled forms, either single-chambered ('monothalamous') or multichambered ('polythalamous'), and soft-shelled monothalamous forms with organic (transparent) or agglutinated tests that placed in the orders Allogromiida and Astrorhizida, respectively, of morphology-based classifications (Kaminski, 2014). In the Black Sea, soft-walled foraminifera include 13 valid species and a large number of undescribed morphospecies (27) that have been identified to genus level, together with more than 60 morphotypes identified only to family level. Representatives of these protists from various coastal and deepwater areas of the Black Sea are available in the collection of the Institute of Biology of the Southern Seas of RAS.

Based on morphological features, they are referred to the families Allogromiidae, Saccam- 
minidae and Psammosphaeridae and require further detailed taxonomic study (incertae sedis). According to our incomplete data, two species, Bellarium rotundum Anikeeva, Sergeeva et Gooday, 2013 and Vellaria cf. pellucida Gooday et Fernando, 1992 and at least 10 undescribed morphotypes, inhabit the Azov Sea, including Sivash (Sergeeva et al., 2013; Sergeeva, Anikeeva, 2015, 2018; Sergeeva, 2016).

During the last decade, bottom sediment samples from various regions and across a wide depths range have yielded soft-shelled foraminifers that can be assigned to the subfamily Shepheardellinae. These very elongate forms have linear dimensions that place them within the macrobenthos. Due to methodological errors and lack of knowledge, these forms had previously escaped the attention of benthologists. Their soft, delicate tests fragmented or disintegrated during the washing of bottom sediments through sieves or during centrifugation and were not recognized as benthic organisms. In this paper, we describe only those species represented by more or less intact specimens, allowing them to be properly described. Unfortunately, we did not have material suitable for genetic analysis, and the descriptions are based entirely on morphological characters.

Representatives of the genus Nemogullmia are reported here for the first time from the Black Sea. These organisms were formerly unknown to researchers of Black Sea macro- or meiobenthos, despite their significant size. Thus, it is very important to make available our data on the diversity and distribution of these foraminifera, and to highlight the difficulties of obtaining material in good condition for further study of their taxonomy by modern methods.

\section{Material and methods}

Samples were obtained in April 2010 in the area of the Bosphorus Strait outlet to the Black Sea, during cruise 15/1 of the R/V "Maria S. Merian" (Germany) in the framework of the European Union project "Hypox". The meiobenthos of the shelf and the upper slope in this area was studied along depth transects from 80 to $296 \mathrm{~m}$ water depth, where less saline surface waters of the Black Sea interact with the saline Mediterranean waters, creating a special ecological system and rapid transitions from oxic, to hypoxic and anoxic bottom-water conditions. Samples for biological studies were collected using a multiple-corer (internal diameter of tubes $9.6 \mathrm{~cm}$ ) that obtains virtually undisturbed sediment samples. The sediment cores were sliced into $1 \mathrm{~cm}$ thick layers down to a depth of 5-10 $\mathrm{cm}$ depth in order to study a vertical distribution of the fauna. All sediment sections were preserved in $75 \%$ ethanol, which is known to preserve morphological structures of fauna without distortion.

Meiobenthos in the Kerch region was studied using material obtained during a benthic survey performed by the Institute of Geological Sciences of the National Academy Science of Ukraine and the Institute of Biology of the Southern Seas of NASU in the $75^{\text {th }}$ cruise of the R/V "Professor Vodyanitsky" in August 2013. This area is located in the NE part of the Black Sea, where active methane seepage is observed. During this cruise a gravity-coring device (diameter $127 \mathrm{~mm}$ ) that obtains virtually undisturbed sediment samples was used. The upper 5$\mathrm{cm}$ layer of sediment as well as the core-top water was included in the faunal analysis.

Samples for meiobenthos were obtained in the NW part of the Black Sea in Karkynitsky gulf near cape Tarkhankut ( $30 \mathrm{~m}$ depth) using an "Ocean-25" sediment corer in May 2013 during the $72^{\text {th }}$ cruise of R/V "Professor Vodyanitsky" (IBSS).

Bottom sediments from the Cape Small Utrish region (82-194 $\mathrm{m}$ depth) were sampled using a box corer (surface area $0.1 \mathrm{~m}^{2}$ ) during the cruise of the R/V "Ashamba" in July 2019.

Sediment samples from the study areas were washed through two sieves, the upper one with a mesh size of $1 \mathrm{~mm}$, the lower one with a mesh size of $63 \mu \mathrm{m}$, and stained with Rose Bengal solution before being sorted for "live" (i.e., stained) foraminifera under a stereo-microscope. Only those specimens that stained intensely with rose Bengal and showed no signs of morphological damage were extracted using a Bogor- 
ov chamber. The core-top water overlying the sediment was analyses separately.

The isolated organisms were first assigned to higher taxa before being identified to genus and species level, where possible, using an Olympus CX41 microscope and Mikmed-6 compound microscope. Microphotographs were obtained by using an Olympus E-410 and Canon A620 digital cameras. Measurements of foraminifera were made using the computer program QuickPhoto Micro 2.3 for processing of digital images.

All holotypes and paratypes of the new species are deposited in the collection of the Institute of Biology of the Southern Seas of RAS, Sevastopol, Russia.

\section{Results}

The systematics of soft-shelled monothalamid foraminifera is still at an early stage of development in comparison with hard-shelled forms. New morphotypes of these organisms are constantly being discovered in marine areas as well as freshwater bodies. Here, we follow the classification adopted by the WoRMS (Hayward et al., 2019).

The systematic position of the new species is defined as follows:

Supergroup Rhizaria Cavalier-Smith, 2002

Phylum Foraminifera d'Orbigny, 1826

Class Monothalamea Haeckel, 1862 (by Pawlowski et al., 2013)

Order Allogromiida Loeblich et Tappan, 1961

Family Allogromiidae Rhumbler, 1904

Subfamily Shepheardellinae Loeblich et Tappan, 1984

Genus Nemogullmia Nyholm, 1953

DIAGNOSIS. Test free or may inhabit empty foraminiferal tests or worm tubes, elongate, straight, or convoluted, $1.6 \mathrm{~mm}$ to $19.0 \mathrm{~mm}$ in length; wall smooth, transparent, whitish to pale red, may have some agglutinated material, intermittent constrictions may occur; temporary small apertures at ends of test; cytoplasm opaque, containing oil droplets, one or more nuclei, pseudopodia reticulose; sexual reproduction with biflagellate gametes that develop within test of uninucleate gamont following temporary closure of apertures; schizont multinucleate, reproducing by fission (Nyholm, 1953: 105; modified by Loeblich, Tappan 1987: 15).

This genus currently contains only one species N. longevariabilis Nyholm, 1953 (Hayward et al., 2019), although representatives of the genus Nemogullmia sp., as incertae sedis, are mentioned in a number of publications (Pawlowski et al., 2003; Gooday et al., 2005).

\section{Nemogullmia pontica sp.n. \\ Figs. 1, 2, Table 1.}

ETYMOLOGY. The species name refers to ancient name of the Black Sea (lat. "Pontus Euxînus"), where this species was found for the first time.

TYPE MATERIAL. The holotype, accession number Meib.1. Al. h, and two paratypes, No. Meib.2. A1. p1; Meib.3. Al. p2, were enclosed in glycerol-gelatine.

TYPE LOCALITY. The holotype (Fig. 1) was collected on July 2013 during $75^{\text {th }}$ cruise $\mathrm{R} /$ V "Professor Vodyanitsky" in the NE part of the Black Sea near the Kerch Strait in the area of methane seeps at $90 \mathrm{~m}$ depth $\left(44^{\circ} 45.2331^{\prime} \mathrm{N}\right.$, $36^{\circ} 09.2240^{\prime} \mathrm{E}$ ). It was extracted from core-top water overlying pelitic silt with admixture of dead mollusks shells. Sampling of core-top water and bottom sediments for biological studies was carried out using a geological coring tube $(\varnothing=127 \mathrm{~mm})$.

The two paratypes (Fig. 2) originated from different localities. One (Fig. 2A-C) was collected in April 2010 in the area of the Bosphorus Strait (Station 203; $41.4990^{\circ} \mathrm{N}, 29.2888^{\circ} \mathrm{E}$; $252.4 \mathrm{~m}$ depth) in black pelitic silt with a strong smell of hydrogen sulfide and a large number of aggregates of filamentous fungi and bacterial mats. The second specimen (Fig. 2D-G) was collected in May 2013 during the 72nd cruise of RV "Professor Vodyanitsky" in the NW part of the Black Sea in Karkynitsky gulf near cape Tarkhankut $\left(45^{\circ} 35.070^{\prime} \mathrm{N}, 32^{\circ} 31.090^{\prime} \mathrm{E} ; 30 \mathrm{~m}\right.$ depth) in fine sandy silt with a small number of shells and live mussels. 


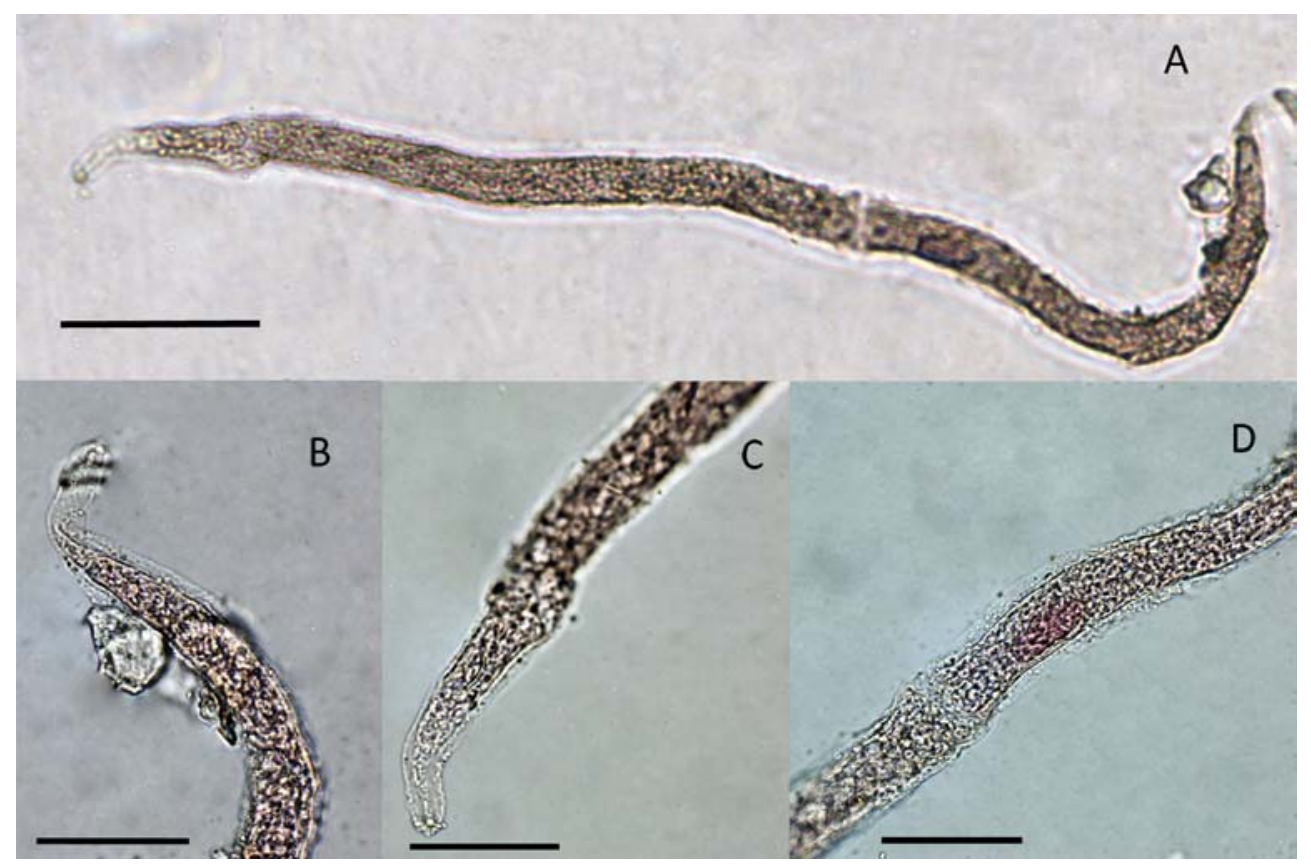

Fig. 1. Nemogullmia pontica sp.n., holotype; A - overall view of the specimen, B, C - two similar terminal apertures, D - nucleus. Scale bar: A - $100 \mu \mathrm{m}, \mathrm{B}-\mathrm{D}-50 \mu \mathrm{m}$.

Рис. 1. Nemogullmia pontica sp.n., голотип; А - общий вид образца, В, С - две идентичные терминальные апертуры, D - ядро. Масштаб: A - 100 мкм, B-D - 50 мкм.

Table 1. Morphological metrics (in $\mu \mathrm{m}$ ) for Nemogullmia pontica sp.n., N. longissima. sp.n. and N. bosphorica sp.n. Таблица 1. Морфологические показатели (в мкм) для Nemogullmia pontica sp.n., N. longissima. sp.n. и $N$. bosphorica sp.n.

\begin{tabular}{|l|c|c|c|c|c|}
\hline \multicolumn{1}{|c|}{ Specimen } & $\begin{array}{c}\text { Length } \\
(\mathrm{s})\end{array}$ & $\begin{array}{c}\text { Width } \\
(\mathrm{h})\end{array}$ & $\begin{array}{c}\text { Length/ } \\
\text { Width ratio }\end{array}$ & $\begin{array}{c}\text { Aperture } \\
(\mathrm{S} \times \mathrm{H})\end{array}$ & Nucleus \\
\hline N. pontica (holotype) & 730 & $18-26$ & $28-40$ & $32 \times 10$ & $30 \times 12$ \\
\hline N. pontica (paratype 1) & 1800 & $44-62$ & $29-41$ & $52 \times 24$ & invisible \\
\hline N. pontica (paratype 2) & 1250 & $18-30$ & $41-69$ & $\begin{array}{c}26 \times 10 ; 18 \\
\times 7\end{array}$ & $23 \times 36$ \\
\hline N. longissima (holotype) & 3200 & $18-32$ & $100-177$ & $34 \times 13$ & $54 \times 29$ \\
\hline N. longissima (paratype1) & 1470 & $11-15$ & $98-133$ & $31 \times 8$ & $36 \times 7-9$ \\
\hline N. longissima (paratype 2) & 1960 & $15-26$ & $75-130$ & $\begin{array}{c}32 \times 15 ; \\
26 \times 13\end{array}$ & $52 \times 21$ \\
\hline N. longissima (paratype 3) & 1000 & $10-20$ & $50-100$ & $15 \times 6$ & $\begin{array}{c}32 \times 6- \\
10\end{array}$ \\
\hline N. bosphorica (holotype) & 1100 & $38-47$ & $21-26$ & $\begin{array}{c}11 \times 9 \\
14 \times 11\end{array}$ & $\begin{array}{c}17 \times 19 \\
(6 \text { nuclei })\end{array}$ \\
\hline N. bosphorica (paratype) & 960 & $45-52$ & $18-21$ & $36 \times 20$ & $\begin{array}{c}17 \times 19 \\
(11 \\
\text { nuclei) }\end{array}$ \\
\hline
\end{tabular}




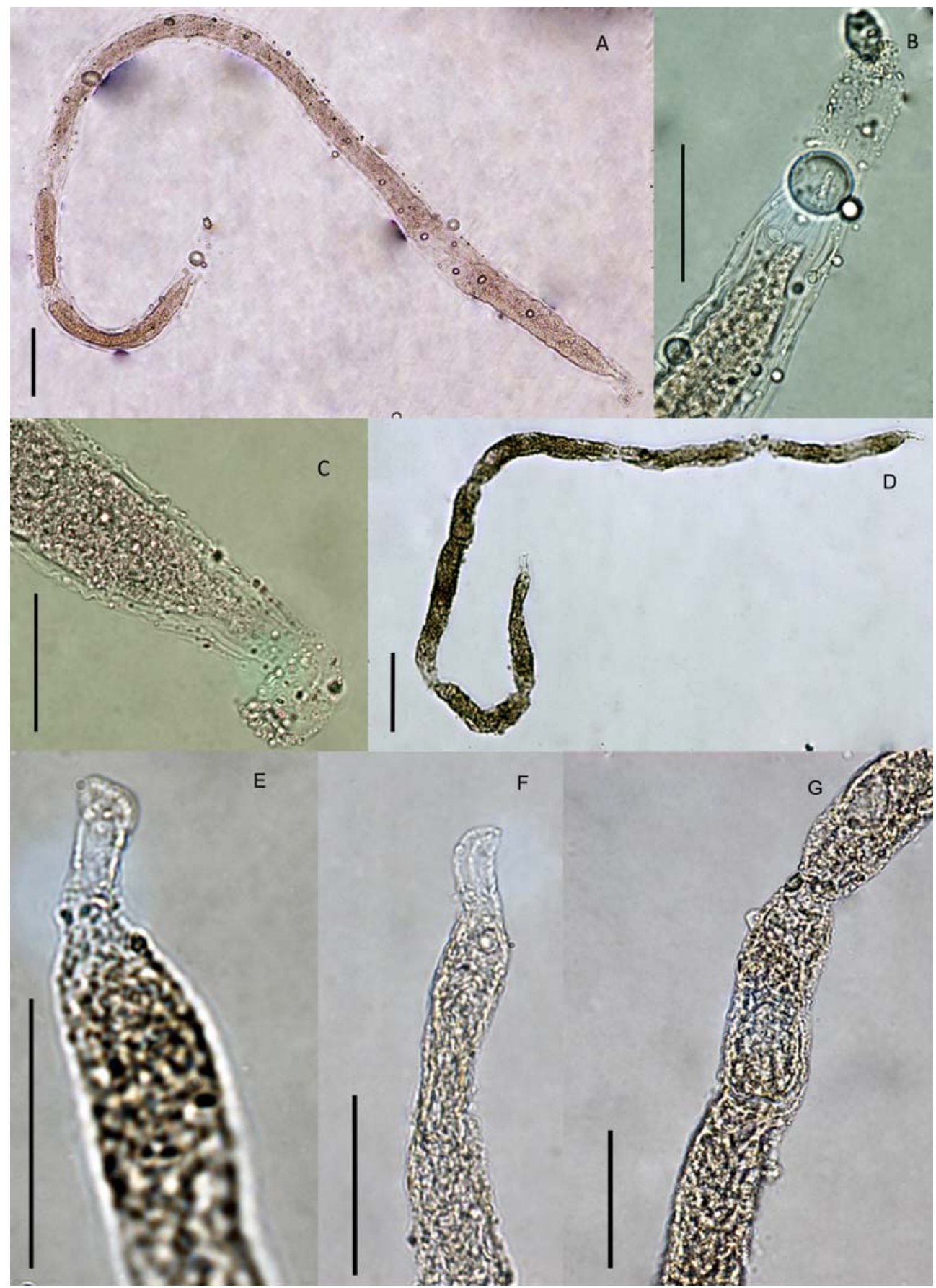

Fig. 2. Nemogullmia pontica sp.n. A-C - paratype 1; D-G - paratype 2: A, D - overall view of the specimen, B, C, E, F - two similar terminal apertures, G - nucleus. Scale bar: A, D - $100 \mu \mathrm{m}, \mathrm{B}, \mathrm{C}, \mathrm{E}-$ $\mathrm{G}-50 \mu \mathrm{m}$.

Рис. 2. Nemogullmia pontica sp.n. А-C - паратип 1; D-G - паратип 2: A, D - общий вид образца, B, C, E, F - две идентичные терминальные апертуры, G - ядро. Масштаб: А, D - 100 мкм, В, C, $\mathrm{E}-\mathrm{G}-50$ мкм. 
DESCRIPTION. Test free, monothalamous, with a long, vermiform shape, ranging from 730 $\mu \mathrm{m}$ long and $26 \mu \mathrm{m}$ wide to $1800 \mu \mathrm{m}$ long and $62 \mu \mathrm{m}$ wide. Length/width ratio varies from 28 40 (in holotype) to 41-69 (in one of paratypes) (Table 1). Test wall flexible, transparent, and composed of organic material. Protoplasm granular and homogeneous with a large oval, slightly oblong nucleus, $30 \times 12 \mu \mathrm{m}$ in size, located close to center. Two apertures situated symmetrically at opposite ends of test on elongated, tubular necks, measuring $32 \mu \mathrm{m}$ long and $10 \mu \mathrm{m}$ wide (holotype) and $52 \mu \mathrm{m}$ long and $24 \mu \mathrm{m}$ wide (paratype 1). Paratype 2 has different sizes of apertures necks $(26 \times 10 \mu \mathrm{m}$ and $18 \times 7 \mu \mathrm{m})$. In some places, the cell has constrictions resembling joints.

REMARKS. Based on the form of the test, the number, nature and the location of the apertural structures, and the morphology of the cell, we attribute this Black Sea species to the genus Nemogullmia. It has a transparent test and dense protoplasm, but it is shorter $(730 \mu \mathrm{m}$ to $1.8 \mathrm{~mm})$ than the range (1.6 to $19 \mathrm{~mm}$ ) given in the original description of $N$. longevariabilis of Nyholm (1953).

The new species differs from the monothalamid genus Marenda Nyholm, 1951, in having a much smaller test size as well as the presence of terminal aperture structures. At the same time, the new species is reminiscent of Shepheardella taeniformis Siddall, 1880 in shape and size, the transparent, colorless wall, granular protoplasm and the presence of a large oval nucleus located in the center. Since our study of the Black Sea samples was carried out after their preservation in ethanol, we do not know whether the protoplasm was yellow as in $S$. taeniformis. The main difference between $N$. pontica and $S$. taeniformis is the presence of longer tubular aperture necks.

Unfortunately, we do not have any living specimens, which would make it much easier to confirm the genus identification. At this stage, however, there is every reason to classify this species as a member of the genus Nemogullmia.

\section{Nemogullmia longissima sp.n.}

Figs 3A-C, 4A-K; Table 1.

ETYMOLOGY. The species name reflects the very long test compared to other Black Sea representatives of this genus (lat. "longissima" — the longest).

TYPE MATERIAL. The holotype and three paratypes were fixed in glycerol-gelatine under accession numbers Meib.4. Al. h (holotype) and Meib.5-7. Al. p1-3 (paratypes).

TYPE LOCALITY. The holotype (Fig. 3) was collected in July 2013 in the NE part of the Black Sea near the Kerch Strait in the area of methane seeps $\left(44^{\circ} 45.2331^{\prime} \mathrm{N}, 36^{\circ} 09.2240^{\prime} \mathrm{E}\right.$; $90 \mathrm{~m}$ depth) during the $75^{\text {th }}$ cruise $\mathrm{R} / \mathrm{V}$ “Professor Vodyanitsky". It was obtained from coretop water overlying pelitic silt with some dead mollusks shells.

One paratype (Fig. 4A-C) was collected in July 2013 during the $75^{\text {th }}$ cruise R/V "Professor Vodyanitsky" near Kerch region (St. 50, depth $79 \mathrm{~m}$ ). The two other paratypes (Fig. 4D-G, H$\mathrm{K})$ were collected during the same cruise from the north-eastern area of the Black Sea near Kerch Strait (depth $88 \mathrm{~m}$ ) in dense pelitic silt with live and dead specimens of the bivalve Modiolula phaseolina.

DESCRIPTION. Test free, monothalamous, long and thread-like in shape; ranging from $1470 \times 15 \mu \mathrm{m}$ to $3200 \times 32 \mu \mathrm{m}$ in length and width, respectively. Organic test wall thin, flexible, and transparent. Dense cell body separated from wall by a distinct space. It varies in width along length of test, probably as a result of preservation in ethanol (Table 1).

Protoplasm granular, homogeneous, and contains one or more nuclei $(52 \times 21 \mu \mathrm{m}$ in size $)$ located close to center. Two apertures situated symmetrically at opposite ends of test on tubular necks, $32 \mu \mathrm{m}$ long and $15 \mu \mathrm{m}$ wide on average.

REMARKS. Nemogullmia longissima is distinguished from $N$. pontica by the greater length of the test (1000-3200 $\mu \mathrm{m}$ for $N$. longissima and $730-1800 \mu \mathrm{m}$ for $N$. pontica), its relatively narrower width, and the much greater (by a factor of three or more) length/width ratio. As a result of its extreme length, the test of $N$. longissima is much more flexible and fragile than that of. N. pontica. The test size of N. longissima fits within the size range of $N$. longevariabilis, but the shape of the nucleus is different. $N$. longissima has one elongated nucleus with even 


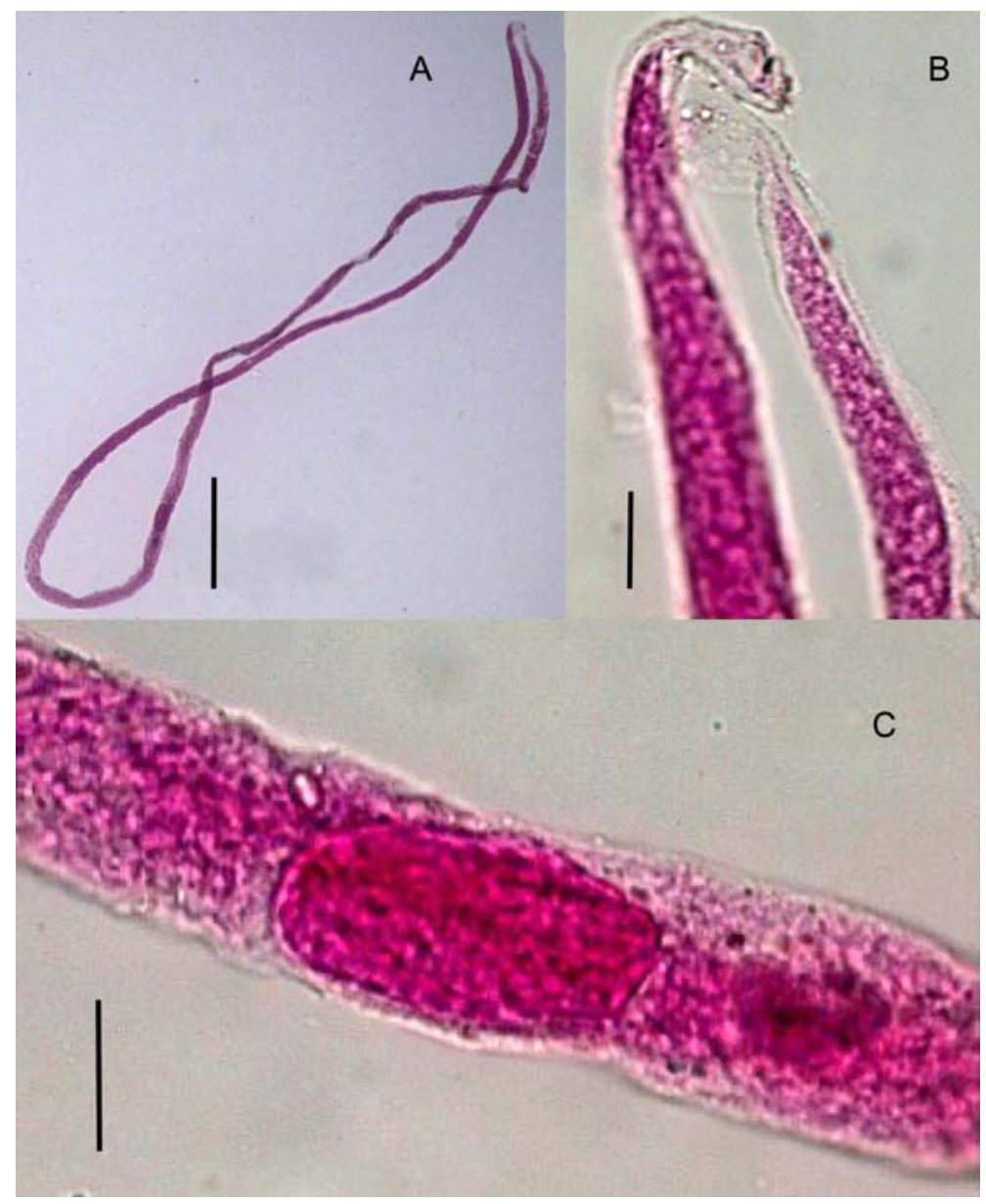

Fig. 3. Nemogullmia longissima sp.n., holotype: A — entire specimen, B - apertures, C - nucleus. Scale bar: $\mathrm{A}-200 \mu \mathrm{m}, \mathrm{B}-20 \mu \mathrm{m}, \mathrm{C}-50 \mu \mathrm{m}$.

Pис. 3. Nemogullmia longissima sp.n., голотип: А - общий вид образца, В - апертуры, С - ядро. Масштаб: A -200 мкм, B -20 мкм, $\mathrm{C}-50$ мкм.

edges, while $N$. longevariabilis has a nucleus with an uneven contour.

\section{Nemogullmia bosphorica sp.n.}

Fig. 5A-G, Table 1.

ETYMOLOGY. The species name refers to an ancient name of the Black Sea, where this species was found for the first time (lat. "navita Bosphorum").

TYPE MATERIAL. The holotype and paratype were fixed in glycerol-gelatine under accession No. Meib.8. Al h (holotype) and No. Meib.9. Al. p1 (paratype).
TYPE LOCALITY. The holotype was collected in the outer area of the Bosporus Strait (St. 298; $41^{\circ} 3718 \mathrm{~N}, 29^{\circ} 1387 \mathrm{E}$; depth $82 \mathrm{~m}$ ) in dense silt with mussel shells. The upper 6-7 cm of sediment consisted of dark grey silt overlying black sulfidic sediment.

The paratype was collected in the same area of the Black Sea (St. 275; $41^{\circ} 4797$ N, $29^{\circ} 2488$ $\mathrm{E}$; depth $135 \mathrm{~m}$ ) in a 4-cm thick layer of dense oxidized sandy silt overlying sulfidic sediment.

DESCRIPTION. Holotype. Monothalamous test, $1100 \mu \mathrm{m}$ long, with a flexible, elastic, transparent and colorless wall. Width fairly 


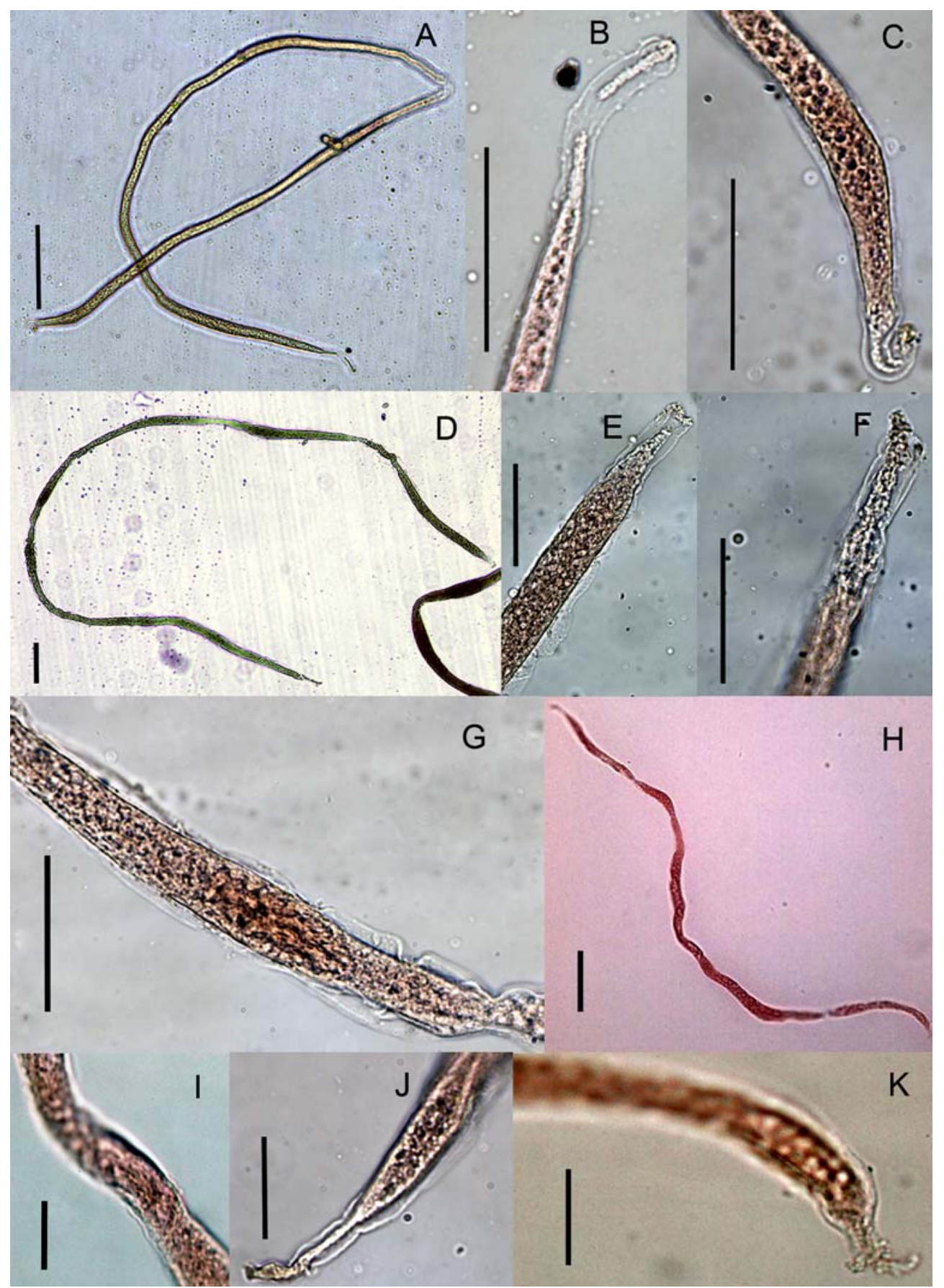

Fig. 4. Nemogullmia longissima sp.n. A-C - paratype 1; D-G - paratype 2, $\mathrm{H}-\mathrm{K}$ - paratype 3: A, D, Hentire specimen, B, C, E, F, J, K - apertures, G, I - nucleus. Scale bars: A, D, H - $100 \mu \mathrm{m}, \mathrm{B}, \mathrm{C}, \mathrm{E}, \mathrm{F}$, $\mathrm{G}-50 \mu \mathrm{m}, \mathrm{I}, \mathrm{K}-20 \mu \mathrm{m}, \mathrm{J}-25 \mu \mathrm{m}$.

Pис. 4. Nemogullmia longissima sp.n. A-C - паратип 1; D-G - паратип 2; H-K - паратип 3: A, D, H - общий вид образца, В, C, E, F, J, K - апертуры, G, I - ядро. Масштаб: А, D, H - 100 мкм, В, $\mathrm{C}, \mathrm{E}, \mathrm{F}, \mathrm{G}-50$ мкм, I, K - 20 мкм, J -25 мкм. 


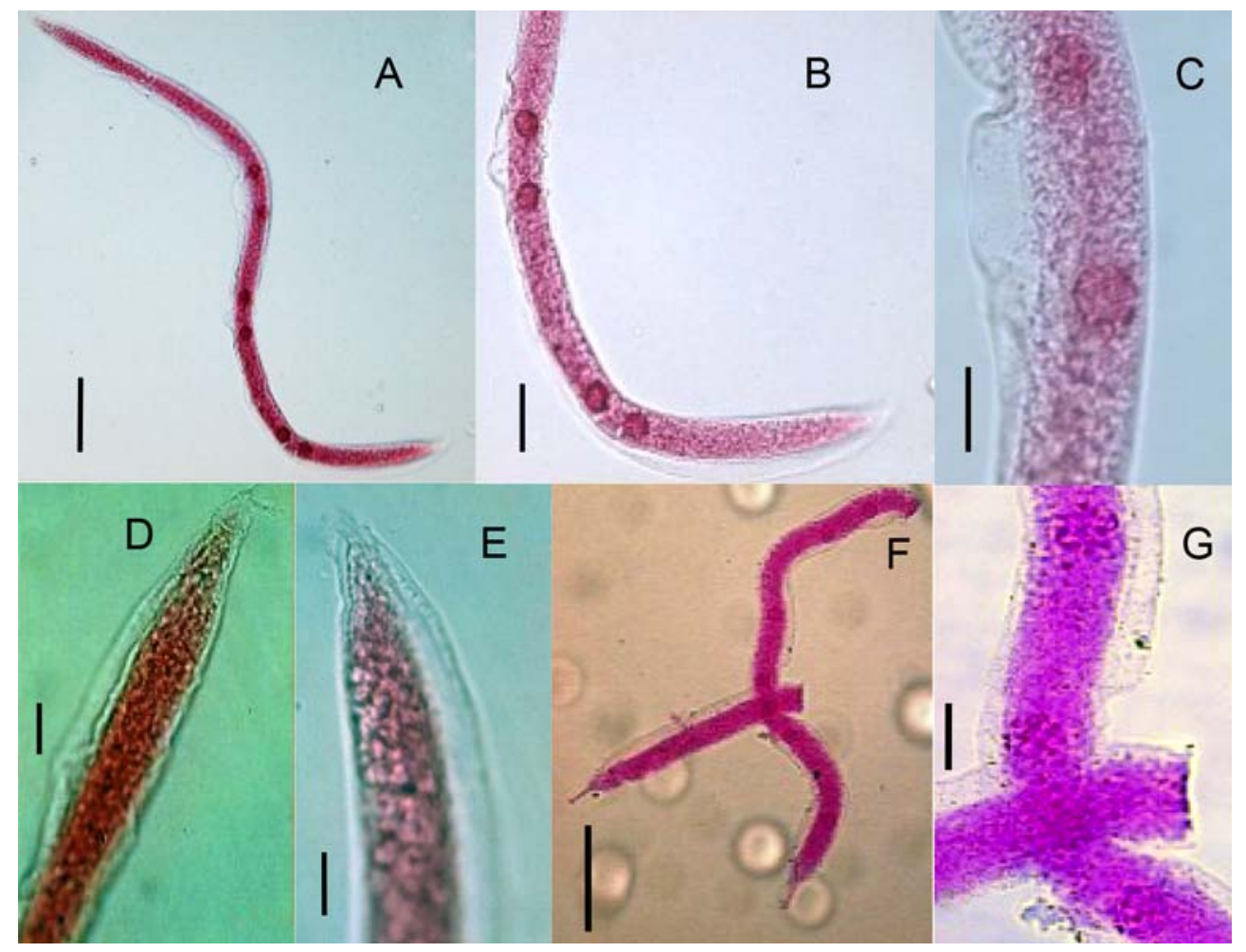

Fig. 5. Nemogullmia bosphorica sp.n. A-E - holotype; F-G - paratype: A - entire specimen, B, C, G nuclei, D, E - the apertures; F — entire specimen (the specimen was broken into two parts during examination). Scale bars: A, F $-100 \mu \mathrm{m}, \mathrm{B}-50 \mu \mathrm{m}, \mathrm{C}, \mathrm{D}, \mathrm{E}, \mathrm{G}-20 \mu \mathrm{m}$.

Рис. 5. Nemogullmia bosphorica sp.n. А-E - голотип; F-G - паратип: А - общий вид образца; В, С, $\mathrm{G}$ - ядра; D, E - апертуры, F - общий вид образца (образец был разделен на две части во время исследования). Масштаб: А, F - 100 мкм, В - 50 мкм, C, D, E, G - 20 мкм.

uniform $(38-47 \mu \mathrm{m})$ along length of test but slightly narrows towards two similar terminal apertures that located at ends of necks $11 \times 9 \mu \mathrm{m}$ and $14 \times 11 \mu \mathrm{m}$ in size (Fig. 5D-E). Test contains moderately granular protoplasm that separated from test wall by a distinct space and contains 6 nuclei, 17-19 $\mu \mathrm{m}$ in size, distributed throughout cell body (Fig. 5B-C).

Paratype. Test $960 \mu \mathrm{m}$ long and 45-52 $\mu \mathrm{m}$ in diameter (Fig. 5F). Terminal apertural necks both $36 \mu \mathrm{m}$ long and $20 \mu \mathrm{m}$ wide. Cell body varies from 22 to $31 \mu \mathrm{m}$ in width (Fig. 5F). Eleven nuclei, 17-19 $\mu \mathrm{m}$ in size, distributed throughout protoplasm (Fig. 5G).

REMARKS. The specimens are probably in the multinucleate (agamont) stage of the life cycle. Nyholm (1956) describes uninucleate and multinucleate forms of $N$. longevariabilis. Specimens of $N$. longevariabilis made up of sausage-like sections separated by constrictions may contain a single vegetative nucleus, or several nuclei. The uninucleate stages of $N$. longevariabilis have a vesicular nucleus, which occupies almost the whole width of the test, with a large nucleolus in the periphery of the nucleus.

The main difference between $N$. bosphorica and $N$. longevariabilis is the much smaller size of the former. A further difference is the arrangement of the rounded nuclei in an ordered row in the Black Sea specimens, as well as their smaller size $(17-19 \mu \mathrm{m})$ compared to those of $N$. longevariabilis $(30 \mu \mathrm{m}$ - from Nyholm, 1956). Finally, the test wall in the Black Sea species is devoid of the agglutinated detritus 
sometimes present in the case of $N$. longevariabilis.

We found several individuals of Nemogullmia on the Caucasus shelf that require further detailed study. At present, we identify them as morphotype Nemogullmia sp.

\section{Discussion}

The fauna of Black Sea hard-shelled foraminifera is well studied (Yanko, Troitskaya, 1987; Yanko, Vorobyova, 1991; Temelkov et al., 2006; Golemansky, 2007). Unlike the forms with a hard shell, fossils of soft-shelled foraminifera are rare, and they are therefore of little interest to micropaleontologists and geologists. This limits what one can learn about the evolution and distribution of these protists in the geological past. All available information about the systematics, ecology, and geographical distribution of allogromiids in the literature has been obtained from the study of modern forms. Despite this lack of information about the geological history of soft-shelled foraminifera, some authors have assumed that the ancestors of all other foraminifera are to be found among representatives of Allogromiida with proteinaceous shells (Bernhard et al., 2006). It has been suggested that the origin of single-chambered foraminifera substantially precedes the appearance of multi-chambered species (Pawlowski et al., 2003).

Allogromiids are known to occur in most aquatic settings, ranging from moist terrestrial soils to hadal trenches (Meisterfeld et al., 2001; Gooday et al., 2008; Lejzerowicz et al., 2010). The habitats occupied by allogromiids in aquatic environments are also diverse; they include normoxic, anoxic (i.e., lacking detectable oxygen) and sulfidic environments (i.e., enriched in hydrogen sulfide), for example, in the Black Sea (Gooday et al., 2006; Sergeeva et al., 2010, 2012, 2017; Sergeeva, Mazlumyan, 2015; Sergeeva, Anikeeva, 2018) and the Santa Barbara Basin, California (Bernhard et al., 2006). However, our limited knowledge of the morphology and taxonomic diversity, biology and ecology of soft-walled foraminifera, as well as their role in marine biochemical cycling, explains why many benthic ecologists overlook them. Based on our own data, we can state that these unicellular eukaryotes are very diverse, numerous, and play an important role in elemental cycling in the benthic ecosystems of the Azov and Black Seas (Sergeeva, 2016; Sergeeva et al., 2017). This paper presents the first record of members of the monothalamid subfamily Shepheardellinae from the Black Sea. These foraminifers are distributed in various regions of the Sea from coastal zones (depths of 10-15 m) to deepwater $(250 \mathrm{~m})$, indicating a significant degree of tolerance to the deficiency of dissolved oxygen and the presence of hydrogen sulfide in some of these habitats.

New suprageneric classifications of the Foraminifera (Mikhalevich, 2013; Pawlowski et al., 2013) emphasize the test morphology as the most conservative feature, while the wall composition and ultrastructure are considered to have important but nevertheless subordinate significance. According to Adl et al., (2012), the Foraminifera belongs to the Supergroup Rhizaria, and is regarded as a phylum that encompasses five classes, including the Class Astrorhizata, Saidova 1981 (= the paraphyletic 'monothalamids' of Pawlowski et al., 2013, in part). The Order Allogromiida Fursenko, 1958 includes five families, among them the Allogromiidae Rhumbler, 1904 and Shepheardellidae Loeblich et Tappan, 1948. Thus, at present, there are different schools of foraminiferal researchers and as yet no single approach to the taxonomy of this group, even at the level of high taxa. As noted above, we were guided in this work by WoRMS (Hayward et al., 2019).

The new species of the subfamily Shepheardellinae described here were found in welloxygenated environments of the Black Sea, as well as in hypoxic and anoxic settings where hydrogen sulfide was present in the bottom water and sediments. This range of habitats emphasizes the high degree of tolerance of these organisms to different environmental conditions. Based on the fragility of their thin-walled organic tests, it is unlikely that they could be transported intact between different parts of the 
Black Sea by near-bottom flows. These organisms are so delicate that they can be easily broken into fragments by a dissecting needle. Therefore, in order to study them, it is necessary to use gentle methods to process bottom sediments and extract them from the sieved sediment residues. We conclude that a well-focused effort to identify allogromiids, based on a combination of morphological analysis and molecular data, is an important research goal for future studies of Black Sea benthos.

Acknowledgements. The work has been conducted within the frameworks of the EU FP7 projects HYPOX 226213 in 2009-2010, a project funded by the Expedition Council of the National Geographic Society in 2011 and the National Programs of NAS Ukraine and the RAS Russia (2013 and 2015-2018). We are grateful to Professor Antje Boetius for providing an opportunity to participate in project «Hypox» and cruise 15/1 RV 'M.S. Merian' and to all participants of this cruise for their help. The analysis of monothalamous foraminifera has been carried out within the framework of the State Programs of the Institute of Biology of the Southern Seas of the Russian Academy of Sciences state registration numbers AAAA-A19119060690014-5 and AAAA-A18$118020890074-2$. This study was also partially funded by the RFBR and the Government of Sevastopol (research project state registration number 18-44-920024). We are very appreciated to Prof. Andrew Gooday for valuable advice and help in editing the English version of the manuscript that greatly improved our paper. We sincerely thank our colleagues of IBSS RAS Dr's. Natalya Boltachova, Nikolay Revkov and Sofia Mazlumyan for their cooperation in the material collecting during cruises. The authors also thankful to Dr. G.A. Kolyuchkina from IO RAS and Dr. V.A. Timofeev from IBSS RAS for providing us the samples of bottom sediments from the Caucasian shelf, that were received in frame by Russian foundation for basic research (RFBR) grant No. 19-45-230012 r_a (IO RAS). We are grateful to Olga Kuleshova and Tatyana Revkova for help in creating and editing of some photos. We thank the anonymous reviewers for detailed comments that helped to improve the paper considerably.

\section{References}

Adl S.M., Simpson A.G.B., Lane C.E., Lukes L., Bass D., Bowser S.S, Spiegel F.W. 2012. The revised classification of eukaryotes // J. Eukaryot. Microbiol. Vol.59. P.429-493.

Anikeeva O.V., Sergeeva N.G., Gooday A.J. 2013. Two new genera and species of the monothalamous foraminifera from coastal waters of the Black Sea // Mar. Biodiv. Vol.43. No.4. P. 473-479.

Bernhard J.M., Habura A., Bowser S.S. 2006. An endobiont-bearing allogromiid from the Santa Barbara Basin: Implications for the early diversification of foraminifera // J. Geophys. Res. Vol.111: G03002. https://doi:10.1029/2005JG000158

Douglas R. 1964. An occurrence of Shepheardella Siddal (Foraminiferida) from the west coast at North America // J. Protozool. Vol.11. No.4. P.484-486.

Golemansky V. 1999. Lagynis pontica n.sp., a new monothalamous rhizopod (Granuloreticulosea: Lagynidae) from the Black Sea littoral // Acta Zool. Bulg. Vol.51. P.3-13.

Golemansky V. 2007. Testate amoebas and monothalamous foraminifera (Protozoa) from the Bulgarian Black Sea coast// V. Fet, A. Popov (eds.). Biogeography and Ecology of Bulgaria. Monographiae Biologicae. Springer, Dordrecht. Vol.82. P.555-570.

Gooday A.J. 2002. Organic-walled allogromiids: aspects of their occurrence, diversity and ecology in marine habitats // J. Foram. Res. Vol.32. P.384-399.

Gooday A.J., Holzmann M., Guiard J., Cornelius N., Pawlowski J. 2004. A new monothalamous foraminiferan from 1000-6300 $\mathrm{m}$ water depth in the Weddell Sea: morphological and molecular characterization // Deep-Sea Res.II. Vol.51. P.1603-1616.

Gooday A.J., Anikeeva O.V., Sergeeva N.G. 2006. Tinogullmia lukyanovae sp. nov. a monothalamous, organic-walled foraminiferan from the coastal Black Sea // J. Mar. Biol. Ass. UK. Vol.86. P.43-49.

Gooday A.J., Anikeeva O.V., Pawlowski J. 2011. New genera and species of monothalamous Foraminifera from Balaclava and Kazach'ya Bays (Crimean Peninsula, Black Sea) // Mar. Biodiv. Vol.41. P.481-494.

Gooday A.J., Bowser S.S., Cedhagen T., Cornelius N., Hald D.M., Korsun S., Pawlowski J. 2005. Monothalamous foraminiferans and gromiids (Protista) from western Svalbard: a preliminary survey // Mar. Biol. Res. Vol.1. P. 290-312.

Gooday A.J., Todo Y., Uematsu K., Kitazato H. 2008. New organic-walled Foraminifera (Protista) from the ocean's deepest point, the Challenger Deep (western Pacific Ocean) // Zool. J. Linn. Soc. Vol.153. P.399-423.

Hayward B.W., Le Coze F., Vachard, D. Gross O. 2019. World Foraminifera Database. Nemogullmia Nyholm, 1953. Accessed through: World Register of Marine Species at: http://www.marinespecies.org/aphia. php?p=taxdetails\&id=111989 on 2019-12-11

Kaminski M.A. 2014. The year 2010 classification of the agglutinated foraminifera // Micropaleont. Vol.61. P.89-108.

Lejzerowicz F., Pawlowski J., Fraissinet-Tachet L., Marmeisse R. 2010. Molecular evidence for widespread occurrence of Foraminifera in soils // Envir. Microbiol. Vol.12. P.2518-2526. 
Lipps J.H., Valentine J.W. 1970. The role of Foraminifera in the trophic structure of marine communities // Lethaia. Vol.3. P.279-286.

Loeblich A., Tappan H. 1984. Suprageneric Classification of the Foraminiferida (Protozoa) // Micropaleont. Vol.30. No.1. P.1-70.

Loeblich A., Tappan H. 1987. Foraminiferal genera and their classification. NY, Van Nostrand Reinhold Comp. 2 vols. 970 p., 847 pl.

Mare M.F. 1942. A study of a marine benthic community with special reference to the microorganisms // Mar. Biol. Ass. UK. Vol.25. P.517-554.

Meisterfeld R., Holzmann M., Pawlowski J. 2001. Morphological and molecular characterization of a new terrestrial allogromiid species: Edaphoallogromia australica gen. et sp. nov. (Foraminifera) from Northern Queensland (Australia) // Protist. Vol.152. No.3. P.185-192.

Mikhalevich V.I. 2013. New insight into the systematics and evolution of the foraminifera // Micropaleont. Vol.59. No.6. P.493-527.

Murray J.W. 2006. Ecology and Applications of Benthic Foraminifera. Cambr. Univ. Press. 426 p.

Nyholm K.-G. 1951. A new monothalamous foraminifer, Marenda nematoides n. gen., n. sp. // Contrib. Cushman Found. Foram. Res. Vol.2. P.91-95.

Nyholm K.-G. 1953. Studies on recent Allogromiidae (2): Nemogullmia longevariabilis n. g., n. sp. from the Gullmar Fjord // Contrib. Cushman Found. Foram. Res. Vol.4. No.3. P.105-106.

Nyholm K.-G. 1956. On the life cycle and cytology of the foraminiferan Nemogullmia longevariabilis // Zool. Bidrag Uppsala. Bd.31. P.483-498.

Pawlowski J., Holzmann M., Berney C., Fahrni J., Cedhagen T., Bowser S. 2002. Phylogeny of allogromiid foraminifera inferred from SSU rRNA gene sequences // J. Foram. Res. Vol.32. No.4. P.334-343.

Pawlowski J., Holzmann M., Berney C., Fahrni J., Gooday A.J., Cedhagen T., Habura A., Bowser S.S. 2003. The evolution of early Foraminifera // Proc. Nat. Ac. Sci. USA. Vol.100. P.11494-11498.

Pawlowski J., Holzmann M., Tyszka J. 2013. New supraordinal classification of foraminifera: molecules meet morphology // Mar. Micropaleont. Vol.100. P.1-10.

Sergeeva N.G. 2016. [Soft-walled benthic Foraminifera of the Black Sea and Azov Sea] // A.V. Gaevskaya (ed.). Proc. All-Russian Sci.-Practic. Conf. Mar. Biol. Res.: Achievements and Perspectives. Sevastopol. Vol.2. P.141-145 [in Russian, with English summary].

Sergeeva N.G., Anikeeva O.V. 2006. [Soft-shelled foraminifera (Protozoa, Rhizopoda, Allogromiinae) from the Black Sea: species composition and distribution] // Ekol. morya. Vol.72. P.57-64 [in Russian, with English summary].

Sergeeva N.G., Anikeeva O.V. 2008. Goodayia rostellatum gen. nov. sp. n. (Protozoa) - a monothalamous foraminiferan from the Black Sea // Vestn. Zool. Vol.42. P.467-471.

Sergeeva N.G., Anikeeva O.V. 2014. Soft-walled foraminifera under normoxia / hypoxia conditions in the shallow areas of the Black Sea // M.D. Georgescu (ed.), Foraminifera. Aspects of Classification, Stratigraphy, Ecology and Evolution. New York, Nova Sci. Publ. P.227-247.
Sergeeva N.G., Anikeeva O.V. 2018. [Soft-shelled foraminifera of the Black Sea and the Sea of Azov]. Simferopol: PP "ARIAL". 156p. [In Russian, with English summary]

Sergeeva N.G., Anikeeva O.V., Gooday A.J. 2005. The monothalamous foraminiferan Tinogullmia in the Black Sea // J. Micropaleont. Vol.24. P.191-192.

Sergeeva N.G., Anikeeva O.V., Gooday A.J. 2010. Softshelled, monothalamous foraminifera from the oxic/ anoxic interface (NW Black Sea) // J. Micropaleont. Vol.56. P.393-407.

Sergeeva N.G., Kolesnikova E.A. 1996. [The results of meiobenthic studies in the Black Sea] // Ekol. morya. Vol.45. P.54-62 [in Russian, with English summary].

Sergeeva N.G., Gooday A.J., Mazlumyan S.A., Kolesnikova E.A, Lichtschlag A., Kosheleva T.N., Anikeeva O.V. 2012. Meiobenthos of the oxic/anoxic interface in the Southwestern region of the Black Sea: abundance and taxonomic composition // A.V Altenbach, J.M. Bernhard, J. Seckbach (eds.). Anoxia: Paleontological Strategies and Evidence for Eukaryotes Survival. Dordrecht, Netherlands: Springer. P.369-401.

Sergeeva N.G., Mazlumyan S.A. 2013. Foraminifera under conditions of hypoxia/anoxia at the Istanbul Strait's (Bosporus) outlet area to the Black Sea // A. Gilbert, V. Yanko-Hombach (eds.). Proc. IGCP-610 First Plenary Meeting and Field Trip. Tbilisi, Georgia: LTD Sachino. P.122-125.

Sergeeva N.G., Mazlumyan S.A. 2015. Deep-water hypoxic meiobenthic protozoa and metazoa taxa of the Istanbul Strait's (Bosporus) outlet area of the Black Sea // Ecol. Monteneg. Vol.2. No.3. P.255-270.

Sergeeva N.G., Mazlumyan S.A., Çag?tay N., Lichtschlag A. 2013. Hypoxic meiobenthic communities of the Istanbul strait's (Bosporus) outlet area of the Black Sea // Turk. J. Fish. Aqua. Sci. Vol.13. P.33-41.

Sergeeva N.G., Ürkmez D., Dovgal I.V., Sezgin M. 2017. Protists (Ciliophora, Gromiida, Foraminifera) in the Black Sea meiobenthic communities //J. Black Sea/ Mediter. Envir. Vol.23. No.2. P.121-155.

Sergeeva N.G., Zaika V.E., Anikeeva O.V. 2015. An overview on distribution and abundance of meiobenthic foraminifera in the Black Sea // Ecol. Monteneg. Vol.2. No.1. P.117-134.

Siddall J.D. 1880. On Shepheardella, an undescribed type of marine Rhizopoda; with a few observation on Lieberkühnia // Q. J. Microsc. Sci. Vol.2. No.20. P.130-145.

Suhr S.B., Alexander S.P., Gooday A.J., Pond D.W., Bowser S.S. 2008. Trophic modes of large Antarctic Foraminifera: roles of carnivory, omnivory, and detritivory // Mar. Ecol. Progr. Ser. Vol.371. P.155-164.

Temelkov B.K., Golemansky V.G., Todorov M.T. 2006. Updated checklist of the recent foraminifera from the Bulgarian Black Sea coast// Acta Zool. Bulg. Vol.58. P.17-36.

Yanko V.V., Troitskaya T.S. 1987. [Late Quaternary foraminifera of the Black Sea]. Moscow: Nauka Publ. 100 p. [In Russian]

Yanko V.V., Vorobyova L.V. 1991. Foraminifera of the Bosphorus and the Black Sea // Ekol. morya. Vol.39. P.47-51 [in Russian, with English summary].

Responsible editor A.V. Chernyshev 